\title{
Black Lives and Asian Medicine
}

\section{An Introduction to the Special Issue on "African American Contributions to American Acupuncture"}

\author{
Yi-Li Wu | ORCID: 0000-0003-4375-0672 \\ Department of Women's and Gender Studies and Department of History, \\ University of Michigan, Ann Arbor, MI, USA \\ yiliwu@umich.edu
}

\begin{abstract}
This essay examines the intersections between Asian medicines, racial healthcare inequities, and social justice movements, and explains how they are illuminated by the interviews and essays in this special issue. Important themes include: how the protests following the murder of George Floyd in May 2020 spurred US organizations of alternative, complementary, and integrative medicine to undertake antiracist initiatives; how acupuncturists have been working to properly acknowledge the contributions of African American practitioners in their historical narratives; and how acupuncture may be a useful tool for mitigating racial health disparities.
\end{abstract}

\section{Keywords}

George Floyd - Black Lives Matter - CoviD-19 - health inequities - medical racism - acupuncture 
The data tells us of a devastating impact from Covid-19 on people of African descent, as well as ethnic minorities in some countries, including Brazil, France, the United Kingdom and the United States. MiCHELLE BACHELET, UN High Commissioner for Human Rights, June $2,2020^{1}$

The killing of a Black man at the hands of police is not a new headline in the United States. But never in this generation has such a death catalyzed so strong a response both in and outside the US. From Syria to New Zealand, Kenya to the Netherlands, protesters are taking to the streets and social media in solidarity. They are speaking out against not just the killing of Black Americans by police in the United States, but also the racism and oppression they see where they live.

GREgory WARNER ET AL., "The Global Legacy of George Floyd," June $10,2020^{2}$

How can we create societies that promote human health, well-being, and dignity? How can we take meaningful action to rectify deeply entrenched social injustices? For almost two years now, these questions have been thrust to the forefront of global concerns in powerful ways. As the coviD-19 pandemic raged around the world, it laid bare the deep inequities within and among societies, evident in different levels of baseline health care, inequitable access to lifesaving treatments, and drastically disparate capacities to weather the losses imposed by business and school closures. ${ }^{3}$ The problem of racism and racial health inequities became salient almost immediately. A desire to blame China for the pandemic led to outbreaks of violence and hostility against Asians living or traveling in white-majority countries. ${ }^{4}$ Meanwhile, as Covid-19 case numbers surged, it quickly became clear in many parts of the world that

1 Quoted in a press release: UNOHCHR 202Oa. For a subsequent statement from Bachelet addressing the disproportionate impact of COVID-19 on minority ethnic communities, see UNOHCHR 2O2Ob.

2 Warner et al. 2020.

3 See, for example, Shadmi et al. 2020.

4 Human Rights Watch 2020. 
Indigenous peoples, ethnic minorities, refugees, and other socioeconomically marginalized groups were falling sick and dying at disproportionately high rates - and people of African descent were consistently among the most harmed. ${ }^{5}$ In the US (which as of this writing in mid-2021 accounted for almost 20 percent of confirmed worldwide covid-19 cases and almost 17 percent of deaths) the nationwide death rate for Black people would be more than twice as high as for whites. ${ }^{6}$

Then, on May 25, 2020, George Floyd, an unarmed, forty-six-year old African American man, was killed by police in Minneapolis, Minnesota, who had detained him on suspicion of making a purchase with a counterfeit twentydollar bill. As Floyd lay handcuffed on the ground, then-officer Derek Chauvin knelt with full force on his neck and upper back for 9 minutes and 29 seconds, asphyxiating him to death as Floyd repeatedly cried that he could not breathe and called out for his mother in his last moments of life. ${ }^{7}$ Outrage had already been building over the wanton killings of two other African Americans earlier that year: Ahmaud Arbery, twenty-five, who was pursued and shot on February 23 by three white men who saw him jogging in their neighborhood, and Breonna Taylor, thirty-six, fatally hit by five bullets fired by plainclothes police officers who battered down the door of her apartment on March 13 to search for evidence of suspected drug dealing. ${ }^{8}$

George Floyd's murder, documented in a horrifying cellphone video recorded by then-seventeen-year-old Darnella Frazier, ignited a firestorm. ${ }^{9}$ Throughout the subsequent weeks, in the midst of a global pandemic, an estimated fifteen to twenty-six million people of all races and ethnicities participated in public

5 Cookson and Milne 2020; Working Group of Experts on People of African Descent 2020.

6 According to the World Health Organization Covid-19 dashboard, as of May 25, 2021, the number of confirmed global cases of Covid-19 was $167,252,15$ o, with $3,467,663$ deaths. The US had 32,797,873 confirmed cases, with 584,700 deaths. (covid19.who.int). Siegel et al. 2021 found that in the US, overall standardized age-indexed COVID-19 mortality rates were 2.7 times higher for Black individuals than white. In individual states, the higher rates of deaths for Black people ranged from 1.4 (Oklahoma) to 4.5 (Michigan). Studies of Brazil and the UK include Baqui 2020 and Mathur et al. 2021

7 Levenson 2021. Initially, Chauvin was believed to have knelt on Floyd for 8 minutes and 46 seconds, but during his trial for murder, the official duration was revised.

8 As of April 2021, Arbery's killers face federal hate crime charges as well as state criminal charges. See Balsamo and Bynum 2021. As for Breonna Taylor's case, while the city of Louisville subsequently agreed to pay a $\$ 12$ million wrongful death settlement to Taylor's family, as of this writing no criminal charges in her death have been brought against the officers involved. See Lovan 2020.

9 Treisman 2021. On June 11, 2021, the Pulitzer Prize Board awarded Frazier a Special Citation "for courageously recording the murder of George Floyd, a video that spurred protests against police brutality around the world, highlighting the crucial role of citizens in journalists' quest for truth and justice." See https://www.pulitzer.org/winners/darnella-frazier. 
demonstrations across the US, decrying racism and calling for end to police brutality. ${ }^{10}$ Similar protests arose in solidarity around the globe, uniting those who saw the Black Lives Matter movement as a potent and resonant critique of racism, state violence, and systemic injustice in their own societies. ${ }^{11}$ In the US the depth of public outrage was such that organizations who had previously been indifferent, resistant, or even critical of earlier demands for racial justice now rushed to express their solidarity with African Americans, to declare their opposition to racism, and to affirm that diversity, equity, and inclusion were among their core values. ${ }^{12}$

One palpable shift was a new willingness to remove public displays of symbols and monuments celebrating the "Confederacy," namely the polity formed by Southern states that seceded from the US in 1861 in order to preserve their right to enslave Africans and African-descended people. The widespread outrage over Floyd's brutal murder was a rebuke to those who would mock "political correctness" and claim that Confederate flags and statues were simply benign displays of pride in their Southern heritage. ${ }^{13}$ His death starkly showed that the alacrity with which police resorted to deadly force against African Americans was the direct result of ideologies that systematically dehumanize Black people, casting them as dangerous Others who deserve violence and whose killings do not need to be questioned or redressed. Such ideologies are rooted in racialized hierarchy of imagined human worth that place "white" at the top and "black" at the bottom. ${ }^{14}$ They were historically fostered by and used to justify colonialism, imperialism, and the global traffic in enslaved Africans, and they are embedded in and perpetuated by the social structures that pattern our lives. The call for social justice was thus also a call for individuals and institutions to be "antiracist": to discern how they themselves might be complicit in perpetuating racism - whether through action or inaction - and then to work intentionally to rectify these injustices. ${ }^{15}$

10 Buchanan, Bui, and Patel 2020.

11 By June 12, 2020, protests had been held in "at least 40 countries, representing every continent except Antarctica” (Smith, Wu, and Murphy 2020). See also Warner et al. 2020; Lankes 2021. The Black Lives Matter movement first arose in 2013 as a response to the acquittal of George Zimmerman, who fatally shot Trayvon Martin, an unarmed seventeen-year-old, on February 26, 2012, in Sanford, Florida. Its development into a powerful political force was further spurred by the protests that followed the police killing of Michael Brown, an unarmed eighteen-year-old, on August 10, 2014, in Ferguson, Missouri. See Cullors 2020.

12 See, for example, Duffy 2020.

13 Vigdor and Victor 2021.

14 See notably Kendi 2016.

15 A thorough and accessible analysis of antiracism is Kendi 2019. 
This special issue of Asian Medicine embodies the belief that such concerns are also relevant to the scholars and practitioners who are members of the International Association for the Study of Traditional Asian Medicine and who are readers of this journal. The interpersonal interactions at the heart of healing are inevitably intertwined with wider social and cultural dynamics, and the kind of healing knowledge that is considered legitimate is always linked to larger structures of political and economic power. It is thus appropriate to ask how we, as researchers and practitioners of Asian medicines, can better understand and address the lacunae, emphases, and biases of the fields in which we operate.

\section{The Social and Cultural Structures of Medicine}

The growth of so-called complementary, alternative, and integrative medicines - including those originating in Asia - has been driven by a sustained critique of the shortcomings and omissions of biomedicine, as well as of the models of knowledge and the power relations that sustain it. Indeed, in a world where biomedicine holds sway, to be a practitioner or scholar of Asian medicines is to implicitly call for diversity and inclusion and to resist erasure. It is to affirm that "Asian Knowledge Matters," to insist that therapies originating in the cultures of formerly colonized and semicolonized parts of the world are as worthy of attention and respect as the scientific practices birthed by the imperial West. This felt need to have people to take Asian practices seriously and to represent them accurately notably inspired the special issue on "Asian Medicine and COVID-19" that this journal published earlier this year. ${ }^{16}$

But can one assume that Asian medicines are themselves free from internalized structures of inequity? In an opinion column published in 2018 in the Journal of Alternative and Complementary Medicine (the official journal of the Society for Acupuncture Research), leaders of the Osher Center for Integrative Medicine at the University of California, San Francisco, pointed out the irony that while the American alternative and complementary medicine field was "predicated on medical pluralism and diverse approaches to health and well-being," its clientele was predominantly "well-educated, well-off, white European Americans."17 Numerous scholars, including those published in the pages of Asian Medicine, have also analyzed how practitioners of Asian

16 Stanley-Baker and Yoeli-Tlalim 2021.

17 Chao and Adler 2018. For the Society of Acupuncture Research, see www.acupuncturere search.org. 
medicines in various places are enmeshed in social and cultural systems of values, not least because Asian medicines have had to emulate and accommodate biomedical institutions in order to survive and thrive. We thus might well ask: How have the demographics of their practitioner and patient populations been shaped by prevailing power structures differentiated by socioeconomic class; gender and sexual orientation; and racial, ethnic, caste, or national identification? How has the institutionalization and professionalization of Asian medicine, carried out via standardized curricula, degree programs, accreditation bodies, and licensure, created particular dynamics of power that elevate certain groups while diminishing others?

During the summer of 2020, the organizations declaring support for racial justice in the US also included many integrative medicine organizations who committed themselves to addressing questions pertaining to medicine, society, culture, and power. By late June 2020, John Weeks, then the editor in chief of the Journal of Complementary and Alternative Medicine, was able to list antiracist statements from twenty-one integrative medicine organizations, including professional associations of midwives, yoga therapists, naturopaths, chiropractors, and acupuncturists, as well as research centers and schools of integrative medicine. ${ }^{18}$ Many of these organizations also launched initiatives to increase the racial and ethnic diversity in their leadership and their constituencies, initiatives informed by a deliberate self-examination of how their institutional cultures or structures might embody biases that marginalized underrepresented groups. ${ }^{19}$ Discussions about structural racism also focused attention on the word "Oriental," which appears as a standard descriptor in the names of US organizations that teach and regulate the practice of Asian medicine. Those who called for its elimination pointed out that "Oriental" was an outdated and racist relic of nineteenth-century imperialism and anti-Chinese racism. ${ }^{20}$

Outside the healthcare realm, diverse organizations dedicated to Asiarelated issues also affirmed their support for racial justice. For example, the Association for Asian Studies (for which I serve as a member of the China and Inner Asia Council) committed itself to rectifying the structural sources of anti-Blackness in a professional field that was conventionally assumed to be the natural purview of white and Asian scholars and students, but an unusual career choice for people from other ethnic groups. ${ }^{21} \mathrm{~A}$ variety of Asian

\footnotetext{
18 Weeks 2020a, 2020b.

19 Weeks 202ob, 2020e.

20 Weeks 2o2od; Zanolini 2020.

21 Association for Asian Studies 2020a, 2020b. The underrepresentation of Black scholars and its relation to perceptions of "what kind" of people go into Asian studies is explicitly addressed in Association for Asian Studies 2021.
} 
American groups and individuals similarly called on their communities to combat their anti-Black prejudices and to rediscover and reinvigorate a history of Afro-Asian "allyship" rooted in a shared experience of racial injustice. ${ }^{22}$ They pointed out that the African American civil rights movement had made it politically possible to pass the Immigration and Nationality Act of 1965 which eliminated the long-standing racial quotas designed to suppress the immigration of Asians and other non-Europeans to the US. They noted that stereotypes such as the "model minority" were inherently anti-Black, and they asked people to examine how Asian strivings to be accepted into a white-dominated society might have led to the internalization of anti-Black biases. ${ }^{23}$

During this time, Asian Medicine editor in chief C. Pierce Salguero and I also discussed what response our journal might make. We felt that to contribute meaningfully to antiracist work, we should create something that could endure beyond the current moment and serve as an ongoing resource for education and action. Ultimately, in collaboration with Daniel Burton-Rose, East Asia Area Editor, what emerged was this collection of interviews and essays, configured as an editorial forum. Originally conceived as a special section, it is now being published as one of two special issues this year on current events (the other one being a special issue devoted to CoviD-19). Thanks to a generous contribution from the Women's and Gender Studies Department of the University of Michigan, Ann Arbor, and with the support of our publisher Brill, we are able to publish this special issue in Open Access.

\section{Content of the Special Issue}

We have chosen the theme of "African American contributions to American acupuncture" because it speaks to two ongoing questions that became particularly salient in US complementary, alternative, and integrative medicine circles following the death of George Floyd. The first was how to appropriately recognize - and redress - the racialized dynamics of knowledge and status production that have historically shaped whose contributions are credited and who participates and holds power in the acupuncture field. The second was how Asian medicines - in this case, acupuncture - can be employed as tools of community empowerment and social justice to mitigate racial health

22 A list of several dozen groups and initiatives appears in Roy and Constante 2020. For other examples, see also Iyer 2020; Letters for Black Lives 2020; Ma 2020; Rathi 2020.

23 For studies of the different ways in which Asian immigrants and their descendants historically came to be racialized as "not-Black," see Bow 2010; Wu 2013. 
disparities. ${ }^{24}$ These themes are woven throughout this editorial forum. At its heart are interviews conducted in the summer of 2020 with three African American acupuncturists: Tolbert Small, who learned of acupuncture during a 1972 trip to Beijing with the Black Panther Party and subsequently practiced it and helped disseminate its use in California; Tenisha Dandridge, cofounder and president of the Black Acupuncturist Association, who is developing programs to use acupuncture and acupressure to address racial health disparities; and Denise Tyson, president of the Maryland Society of Acupuncture, who has called on the acupuncture community to educate itself about the history of racism against African Americans and to redress inequity in its professional organizations.

In these interviews, these experts discuss how they came to be interested in acupuncture and describe the interpersonal dynamics that shaped their training, practice, and clientele. They also reflect on race relations, including their personal experiences with racism, and provide a snapshot of their thoughts during a summer when the world was riven with anger and pain, but also holding out hope that some new advance in the long struggle for social justice might be possible. It is too often the case that those who are most harmed by racism must also bear the brunt of the labor in educating others as to racism's harm. We are thus especially grateful to them for their time and willingness to speak to us so openly and frankly. In addition to these interviews, conducted by Burton-Rose and myself, this issue includes two complementary contributions by Harvard University doctoral and medical school student Eana Meng, who is working with Small and others to catalog and preserve his personal archive: a photo essay documenting Small's life and a reflective essay on how the revolutionary history of US acupuncture is relevant to the global trajectories of Asian medicine. Throughout this special issue, we have added copious explanatory footnotes to provide background information for readers who may be unfamiliar with the various cultural and historical references.

One of our main goals is to direct our readers' attention to a story that is unevenly known and often omitted from conventional narratives: the role that Black revolutionary groups played during the 1970s in the dissemination of acupuncture and the creation of acupuncture therapies. A companion goal, illustrated in Meng's essay, is to invite reflection on why history and representation matter. Dehumanization feeds on erasure, the process by which the lives of less powerful individuals are effaced from the historical record and the public consciousness, leaving gaps that are then filled by negative narratives of the very people who have been discriminated against. Examining the work of 
African American acupuncturists, past and present, helps to resist their erasure from white-authored narratives, making visible what has been effaced and correcting what has been distorted.

\section{Healing the Harms of Racism}

In her authoritative study of the Black Panther Party's health activism, Alondra Nelson dismantles the popular image of the BPP as a violent militant group, showing instead that its major motivation was to improve the quality of life for minority communities suffering socioeconomic discrimination and deprivation. ${ }^{25}$ The free medical clinics that the в РP established to "serve the people, body and soul" included the one in Berkeley, California, where Small volunteered his medical services. Meng's essay also introduces another facet of this history that became increasingly visible in 2020: how Black and Puerto Rican revolutionaries pioneered the use of acupuncture to treat drug addiction at the Lincoln Detox Center in New York City's South Bronx area. This clinic was created after the Young Lords and their Black allies occupied the struggling Lincoln Hospital in 1970 and demanded that it be given adequate resources to serve the residents of the economically devastated neighborhoods that surrounded it. Mutulu Shakur (stepfather of the late rapper Tupac) introduced the idea of using acupuncture to treat heroin addiction. The auricular acupuncture treatments that he and his fellow revolutionaries developed to combat the heroin epidemic of that time became the origins of the five-point protocol subsequently standardized by the National Acupuncture Detoxification Association and now used worldwide. Previously, the NADA protocol was credited solely to white practitioner Michael Smith, who founded NADA in 1985. But NADA gradually started to investigate its revolutionary roots and this project accelerated in the summer of 2020 , impelled by calls for racial justice and the availability of new sources, notably filmmaker Mia Donovan's documentary on Mutulu Shakur and the Lincoln Detox Center. ${ }^{26} \mathrm{~A}$ blog post that Dandridge had written on the subject a few years prior also received new attention in June 2020 and helped to publicize this history. ${ }^{27}$

The inequities that the Black Panthers and others sought to address had not emerged organically. Instead, they were the direct result of generations of racist violence and discriminatory policies. Scholars have abundantly documented

\footnotetext{
$25 \quad$ Nelson 2011.

26 Weeks 202Oc.

27 Dandridge $202 \mathrm{O}$.
} 
the numerous ways that white supremacists murdered and terrorized African Americans after slavery was outlawed in 1865 , determined to keep them from claiming equal rights. They both killed individuals and destroyed entire communities. In 1921 racist hatred fueled the white mob that torched and demolished the flourishing Greenwood business district in Tulsa, Oklahoma, then known as "Black Wall Street," killing hundreds. Racism ensured that the perpetrators could act with impunity, and racism enabled a "conspiracy of silence" that erased the massacre from public consciousness until $1971 .^{28}$ This is the history that Tyson urged her fellow acupuncturists to learn, and this is the type of violence that Small's family sought to escape by joining the so-called Great Migration to the northern US.

Beyond acts of physical violence, institutionalized discrimination was also carried out by government and private entities throughout the US. In January 2021 the student newspaper of the University of Michigan (where I teach) reported on a new study showing that housing deeds in sixty-six local neighborhoods still contained racially restrictive covenants, specifying that "no part of said land shall be occupied by persons not of the Caucasian race except as guests or servants." ${ }^{29}$ Although unenforceable, such covenants are difficult to remove from the deeds, remaining to bear witness to a deep history of discriminatory housing and lending practices. This discrimination included policies implemented by the federal government. In the post-wwII era, US government programs subsidized college educations for white veterans and facilitated suburban homeownership for white families, but they explicitly denied these benefits to African Americans. ${ }^{30}$ This restricted the social mobility of African Americans while leading to the degradation of the urban neighborhoods into which many minorities were effectively segregated. This is what Dandridge is referring to when she observes that African Americans were forced to become poor. ${ }^{31}$ The deleterious effects were further reinforced

28 Staples 1999, 2020. This year marks the hundredth anniversary of the massacre and numerous organizations organized events to increase awareness of its history. See the 1921 Tulsa Race Massacre Centennial Commission at https://www.tulsa2O21.org/.

29 Stocking 2021.

$30 \quad$ Important studies are Katznelson 2005 and Rothstein 2017.

31 According to data from the US Census Bureau for 2019, the absolute number of nonHispanic white people in poverty (14.2 million) is far larger than the number of Black people in poverty (8.1 million). However, the poverty rate among the Black population (18.8 percent) is higher than for any other ethnic group, and more than 2.5 times higher than for non-Hispanic whites (7.3 percent). As a result, Black people make up a disproportionately high number of the people in poverty: non-Hispanic white people comprise 59.9 percent of the US population but 41.6 percent of those in poverty, while Black people comprise 13.2 percent of the US population but 23.8 percent of those in poverty. The median income for Black people in 2019 was $\$ 45,438$ compared to $\$ 76$, o57 for 
by discrimination and exclusion in education and employment. Attentive readers may note that the university that Tyson's parents attended was one of the "historically Black colleges and universities" established to serve African Americans during a time when most other schools refused to admit them.

Since racial inequities are a product of human choice, humans can also choose to correct them. The history of the Black Panthers and the Lincoln Detox Center illustrates how acupuncture can be used as a tool for social justice. So too, our interviewees see acupuncture as a tool of personal and community empowerment, whether in healing racial traumas or in serving people who are disenfranchised by the medical establishment. The long and lamentable history of racism in biomedicine includes grotesque violations like the Tuskegee "Study of Untreated Syphilis," carried out on hundreds of Black men by the US Public Health Service from 1932 to 1972. The medical researchers misled the men about their diagnoses and the aims and method of the study. They also allowed them to remain untreated even after penicillin became a standard treatment for syphilis. ${ }^{32}$ The racist ideologies that enabled this dehumanization are still manifest in day-to-day inequities in the diagnosis and treatment of Black patients. For example, African Americans with skin cancer are two to three times more likely to die than whites. Not only do Black individuals experience more delays in treatment after diagnosis, but dermatology itself is structurally biased: medical models, research, and training are based on individuals with lighter skin and on the melanomas caused by sun exposure. This leads doctors to ignore or misdiagnose melanomas that occur on darker skin or that are not related to sun exposure. ${ }^{33}$ Similarly, the doctors and scientists who developed modern anesthesia believed that Black people were less sensitive to pain than whites, a belief echoed in the fact that African American patients are still significantly less likely to be offered pain relief medication than whites. ${ }^{34}$ And such harms start from birth, as Black babies in the US are three times more likely to die than white babies. A recent study of 1.8 million hospital births in Florida found that the mortality rate for Black newborns under the care of a white physician was more than twice as high as those under the care

non-Hispanic whites. See Semega et al. 2020, 4-5, 15. Black people living at higher income levels also face much more economic precarity than their white counterparts. See, for example, USCJEC 2020.

32 Reverby 2009. One of the Tuskegee researchers also subsequently conducted syphilis experiments on prisoners in Guatemala. Whereas the Tuskegee patients were already infected with syphilis before joining the study, the US doctors deliberately infected their Guatemalan subjects with syphilis. See Reverby 2012. The case of Tuskegee exemplifies how medical dehumanization can cross borders under conditions of imperialism. 
of a Black physician, particularly if the baby required complex or challenging treatments. ${ }^{35}$

Both Dandridge and Tyson describe the holistic, individual-centered approach of Asian medicines as a valuable potential corrective to such forms of medical racism. Their desire to make the predominantly white US acupuncture profession more welcoming to and supportive of Black practitioners is also rooted in the belief that this will enhance the profession's ability to do outreach into minority communities. And while these interviews arise from a US context, the larger issues of how racial bias influences well-being and health equity have profound global resonances. As Dandridge points out, racial and generational trauma is not a uniquely African American experience but is found in populations all over the world, notably including those suffering from conflicts and violence fueled by racial or ethnic hostility. To those collective traumas we now add CoviD-19, where health and socioeconomic inequities continue to accumulate one upon another in synergistic fashion, such that the pandemic is also a "syndemic." ${ }^{36}$ As I write today, the optimism that greeted the advent of the COVID-19 vaccine has given way to frustration over inequities in global supply and distribution: rich countries vaccinate millions of people while poorer countries cannot even vaccinate their frontline healthcare workers. ${ }^{37}$ The burden of CoviD-19 morbidity and mortality continues to fall hardest on those who were already most harmed by health inequities.

Asian Medicine's special issue on Covid-19 earlier this year focused attention on the ways that practitioners of Asian medicine have worked to mitigate the direct and collateral harms of CoviD-19. This includes caring for communities that are "epidemiologically invisible" because of socioeconomic class, language, ethnicity, race, national origin, and citizenship status. ${ }^{38}$ In this special issue, we further affirm that practitioners and scholars of Asian medicine have valuable insights to offer into the global problem of how to redress medical inequities in marginalized populations. Ideological hierarchies of human worth exist everywhere, and notions of race, ethnicity, and class routinely intersect with colorism: a preference for light skin and a denigration of darkness. ${ }^{39}$ Thus, while this issue focuses on characteristically US examples, we believe that it will provide a useful point of reference for thinking more broadly about

35 Greenwood et al. 2020.

36 For the syndemic nature of covid-19 outbreaks, see, for example, Caron and Adegboye 2021.

$37 \quad$ Katz et al. 2021; Guterres 2021.

38 Craig et al. 2021, 61.

39 Glenn 2008. 
the ways that conscious and unconscious biases shape the societies in which we practice and study medicine.

And although this special issue was shaped by the events of summer 2020, the problems that it addresses continue to be relevant today. Racial ideologies and structural racism have been continuously reinforced over generations, and it will likewise be the work of generations to dismantle them. For example, in response to Black Lives Matters protests in the UK, Boris Johnson's government formed a commission to investigate "race and ethnic disparities." But the commission's report of March $2021^{40}$ drew widespread condemnation for claiming that racism was no longer a significant factor in social disparities. Many organizations quoted in the report immediately distanced themselves from it, and a body of experts from the United Nations Human Rights Council soon denounced it as a "reprehensible" attempt to "normalize White supremacy."41 Meanwhile, on April 20, 2021 - the same day that a jury convicted Derek Chauvin of murdering George Floyd - police officers in Columbus, Ohio, shot and killed a sixteen-year-old African American girl, igniting outrage and spurring the city's mayor to call for a federal probe into a police department long accused of using excessive force against Black residents. ${ }^{42}$ On May 10, 2021, the families of 165 African Americans killed or maimed by US police sent a letter to the UN High Commissioner for Human Rights calling for an inquiry into police violence against Black people. Their letter was cosigned by over 250 civil society organizations from around the world. ${ }^{43}$

To diagnose and treat the challenges of our time requires us to study and name them, deliberately and thoughtfully, particularly when they are intertwined with dynamics as complex and contested as racial, ethnic, or caste discrimination. We offer this special issue to our readers in the belief that a journal dedicated to the study of medicine should not remain silent in the face of human suffering. We do so with an acute awareness that we ourselves are still in the process of learning how to speak about racial injustice and how to navigate the paths of change. We thus present this special issue in a spirit of

$40 \quad$ Commission on Race and Ethnic Disparities 2021.

41 Mohdin and Walker 2021; Working Group of Experts on People of African Descent 2021.

42 Amiri and Welsh-Huggins 2021.

43 Human Rights Watch 2021. This letter came a month after a United Nations Commission of Inquiry comprising twelve human rights experts from Asia, Africa, Europe, and the Americas issued a 188-page report on "systemic police violence against people of African descent in the United States." It concluded that there was "a prima facie case of Crimes Against Humanity warranting an investigation by the International Criminal Court (ICC)." International Commission of Inquiry on Systemic Police Violence Against People of African Descent in the United States 2021, art. 19, p. 16. 
invitation, with the sincere desire to initiate a conversation that is as difficult as it is necessary. Those of us who are healers are dedicated to improving the well-being of others. Those of us who are scholars are dedicated to improving our understandings of the healing enterprise. We look forward to many future conversations with our readers on these shared concerns.

\section{Acknowledgments}

This special issue would not have been possible without the generous collaboration, expertise, and tireless efforts of Daniel Burton-Rose. I also thank Eana Meng for contributing her invaluable archival work, Pierce Salguero for his steadfast moral support, Colin Garon for his research assistance, Anna Andreeva and Nicole Barnes for their sage editorial comments on this introduction and the interviews, and Jon Wilcox for his patient and precise copyediting. Special thanks to Ruby Tapia who helped me secure funding to defray the Open Access fees. Deepest gratitude goes to our interviewees for entrusting us with their stories.

\section{About the Author}

Yi-Li Wu is an associate professor of women's and gender studies and history at the University of Michigan, Ann Arbor. She is the author of Reproducing Women: Medicine, Metaphor, and Childbirth in Late Imperial China (University of California Press, 2010) and is completing a manuscript on the history of medicine for injuries in China. She is the Senior Editor of Asian Medicine.

\section{Bibliography}

Amiri, Farnoush, and Andrew Welsh-Huggins. 2021. "Columbus Mayor Requests Federal Probe of Police Force." AP News, April 28, 2021. https://apnews.com/article/ death-of-george-floyd-shootings-4c3dfgbo72f 75693 ec248f 41 aoba522o.

Association for Asian Studies. 2020a. "AAS Takes Action to Build Diversity \& Equity in Asian Studies." June 16, 2020. https://www.asianstudies.org/about/aas -takes-action-to-build-diversity-equity-in-asian-studies/.

Association for Asian Studies. 2020b. "Asian Studies and Black Lives Matter." Roundtable, July 20, 2020. https://www.asianstudies.org/jobs-professional-resources/aas-digital -dialogues/asian-studies-and-black-lives-matter/. 
Association for Asian Studies. 2021. 'Call for Papers: 'Who is the Asianist?' The Politics of Representation in Asian Studies." https://www.asianstudies.org/call-for -papers-who-is-the-asianist-the-politics-of-representation-in-asian-studies/.

Balsamo, Michael, and Russ Bynum. 2021. "US Indicts 3 on Hate Crime Charges in Death of Ahmaud Arbery." AP News, April 28, 2021. https://apnews.com/article/ahmaud -arbery-georgia-hate-crimes-crime-government-and-politics-efioıbfbfg6f 3 eeg21 c29c6dcf89e7eb.

Baqui, Pedro, Ioana Bica, Valerio Marra, Ari Ercole, and Mihaela van der Schaar. 2020. "Ethnic and Regional Variations in Hospital Mortality from COVID-19 in Brazil: A Cross-Sectional Observational Study." The Lancet Global Health 8.8: e1018-26. https://doi.org/10.1016/S2214-109X(20)30285-o.

Bow, Leslie. 2010. Partly Colored:Asian Americans and Racial Anomaly in the Segregated South. New York: New York University Press.

Buchanan, Larry, Quoctrung Bui, and Jugal K. Patel 2020. "Black Lives Matter May Be the Largest Movement in U.S. History." New York Times, July 3, 2020. https://www .nytimes.com/interactive/2020/o7/o3/us/george-floyd-protests-crowd-size.html.

Caron, Rosemary M., and Amanda Rodrigues Amorim Adegboye. 2021. "COVID-19: A Syndemic Requiring an Integrated Approach for Marginalized Populations.” Frontiers in Public Health 9, article 67528o (May 11): 1-8. https://doi.org/10.3389/ fpubh.2021.675280.

Chao, Maria T., and Shelley R. Adler. 2018. "Integrative Medicine and the Imperative for Health Justice." Journal of Alternative and Complementary Medicine 24, no. 4: 101-3. https://doi.org/10.1089/acm.2017.29042.mtc.

Commission on Race and Ethnic Disparities. 2021. The Report of the Commission on Race and Ethnic Disparities. Published March 31, updated April 28, 2021. https:// www.gov.uk/government/publications/the-report-of-the-commission-on-race -and-ethnic-disparities.

Cookson, Clive, and Richard Milne. 2020. "Nations Look Into Why Coronavirus Hits Ethnic Minorities So Hard." Financial Times, April 29, 2020. https://www.ft.com/ content/5fd6ab18-be4a-48de-b887-8478a391dd72.

Craig, Sienna R., Nawang T. Gurung, Ross Perlin, Maya Daurio, Daniel Kaufman, Mark Turin, and Kunchog Tseten. 2021. "Global Pandemic, Translocal Medicine: The COVID-19 Diaries of a Tibetan Physician in New York City." Asian Medicine 16, no. 1: $5^{8-88 .}$

Cullors, Patrice. 2021. "Black Lives Matter Began After Trayvon Martin's Death. Ferguson Showed Its Staying Power." NBC News: Think, January 1, 2021. https:// www.nbcnews.com/think/opinion/black-lives-matter-began-after-trayvon-martin -s-death-ferguson-ncna1106651.

Dandridge, Tenisha. 2020. "Unusual Tale of Acupuncture, Racism, and African American History in the USA.” Everyone's Place, June 7, 2020. www.everyones-place 
.com/bipoc-health/unusual-tale-of-acupuncture-racism-and-african-american -history-in-the-usanbsp.

Duffy, Clare. 2020. "In the Face of a Cultural Reckoning, It Turns Out Massive Corporations Can Move Fast and Fix Things." CNN Business, June 21, 2020. https://www.cnn .com/2020/06/21/business/corporate-america-addresses-racism/index.html.

Glenn, Evelyn Nakano. 2008. "Yearning for Lightness: Transnational Circuits in the Marketing and Consumption of Skin Lighteners." Gender \& Society 22, no. 3: 281302. https://doi.org/10.1177/0891243208316o89.

Greenwood, Brad N., Rachel R. Hardeman, Laura Huang, and Aaron Sojourner. 2020. "Physician-Patient Racial Concordance and Disparities in Birthing Mortality for Newborns." Proceedings of the National Academy of Sciences 117, no. 35 (September): 21194-20o. https://doi.org/10.1073/pnas.1913405117.

Guterres, Antonio. 2021. "Remarks at Virtual Meeting with the African Group." United Nations Secretary-General, March 23, 2021. https://www.un.org/sg/en/content/sg/ speeches/2021-03-23/remarks-virtual-meeting-the-african-group.

Hoffman, Kelly M., Sophie Trawalter, Jordan R. Axt, and M. Norman Oliver. 2016. "Racial Bias in Pain Assessment and Treatment Recommendations, and False Beliefs about Biological Differences Between Blacks and Whites." Proceedings of the National Academy of Sciences of the United States of America 113, no. 16: 4296-301. https://doi .org/10.1073/pnas.1516047113.

Human Rights Watch. 2020. "COVID-19 Fueling Anti-Asian Racism and Xenophobia Worldwide." May 12, 2020. https://www.hrw.org/news/2020/05/12/covid-19-fueling -anti-asian-racism-and-xenophobia-worldwide.

Human Rights Watch. 2021. "Coalition Calls for United Nations Inquiry into US Police Violence.” May 10, 2021. https://www.hrw.org/news/2021/o5/10/coalition-calls-united -nations-inquiry-us-police-violence.

International Commission of Inquiry on Systemic Police Violence Against People of African Descent in the United States. 2021. Report of the International Commission of Inquiry on Systemic Police Violence Against People of African Descent in the United States. Report dated March 2021, issued April 15, 2021. https://inquirycommission .org/website/wp-content/uploads/2021/04/Commission-Report-15-April.pdf.

Iyer, Deepa. 2020. "South Asians in the US Must Support \#BlackLivesMatter, But First Undo Your Own Anti-Blackness.” The Print, May 31, 2020. https://theprint.in/opin ion/south-asians-in-the-us-must-support-blacklivesmatter-but-first-undo-your -own-anti-blackness/432754/.

Katz, Ingrid T., Rebecca Weintraub, Linda-Gail Bekker, and Allan M. Brandt. 2021. "From Vaccine Nationalism to Vaccine Equity: Finding a Path Forward." New England Journal of Medicine, April 8. https://doi.org/10.1056/NEJMp2103614.

Katznelson, Ira. 2005. When Affirmative Action Was White: An Untold History of Racial Inequality in Twentieth-Century America. New York: W.W. Norton \& Co, Inc. 
Kendi, Ibram X. 2016. Stamped From The Beginning: The Definitive History of Racist Ideas in America. New York: Nation Books.

Kendi, Ibram X. 2019. How to Be an Antiracist. New York: One World.

Lankes, Catherine. 2021. "How George Floyd's Death Reignited a Worldwide Movement." Deutsche Welle, March 7, 2021. https://www.dw.com/en/how-george-floyds -death-reignited-a-worldwide-movement/a-56781938.

Letters for Black Lives. 2020. https://lettersforblacklives.com/2020/home.

Levenson, Eric. 2021. "Former Officer Knelt on George Floyd for 9 Minutes and 29 Seconds - Not the Infamous 8:46," $c N N$, March 30, 2021. https://www.cnn .com/2021/o3/29/us/george-floyd-timing-929-846/index.html.

Lovan, Dylan. 2020. “Say Her Name': City to Pay $\$ 12 \mathrm{M}$ to Breonna Taylor's Family." AP News, September 15, 2020. https://apnews.com/article/shootings-police-us-news -ap-top-news-racial-injustice-42dfif3ebea59ff2oa3ogb8feo4619df.

Ma, Wenhao. 2020. "Anti-Racism Protests Spark Conversations Within Chinese Immigrant Families." VOA News, June 28, 2020. https://www.voanews.com/usa/race -america/anti-racism-protests-spark-conversations-within-chinese-immigrant -families.

Mathur, Rohini, Christopher T. Rentsch, Caroline E. Morton, William J. Hulme, Anna Schultze, Brian MacKenna, Rosalind M. Eggo, et al. 2021. "Ethnic Differences in SARS-CoV-2 Infection and COVID-19-Related Hospitalisation, Intensive Care Admission, and Death in 17 Million Adults in England: An Observational Cohort Study Using the OpenSAFELY Platform." The Lancet 397, no. 10286: 1711-24. https:// doi.org/10.1016/So140-6736(21)oo634-6.

Mohdin, Aamna, and Peter Walker. 2021. "Bodies Credited in UK Race Review Distance Themselves From Findings." Guardian, April 12, 2021. https://www.the guardian.com/world/2O21/apr/12/bodies-credited-in-uk-race-review-distance -themselves-from-findings.

Nelson, Bryn. 2020. "How Dermatology is Failing Melanoma Patients with Skin of Color." Cancer Cytopathology 128, no. 1: 7-8.

Pernick, Martin. 1985. A Calculus of Suffering: Pain, Professionalism, and Anesthesia in Nineteenth-Century America. New York: Columbia University Press.

Rathi, Nandini. 2020. "Black Lives Matter: South Asian Americans Come to Terms With Their Own Anti-Blackness." Indian Express, June 18, 2020. https://indianexpress .com/article/world/black-lives-matter-south-asian-americans-come-to-terms -with-own-anti-blackness-6465153/.

Reverby, Susan M. 2009. Examining Tuskegee: The Infamous Syphilis Study and Its Legacy. Chapel Hill: University of North Carolina Press.

Reverby, Susan M. 2012. "Ethical Failures and History Lessons: The U.S. Public Health Service Research Studies in Tuskegee and Guatemala." Public Health Review 34, no. 13. https://doi.org/10.1007/BFo3391665. 
Rothstein, Richard. 2017. The Color of Law: A Forgotten History of How Our Government Segregated America. New York: Liveright Publishing.

Roy, Natasha, and Agnes Constante. 2020. "75 Ways Asian Americans and Pacific Islanders Are Speaking Out For Black Lives.” NBC Asian America, June 12, 2020. https://www.nbcnews.com/news/asian-america/75-ways-asian-americans-pacific -islanders-are-speaking-out-black-n1230551.

Semega, Jessica, Melissa Kollar, Emily A. Shrider, and John F. Creamer. 2020. Income and Poverty in the United States: 2019. US Census Bureau, Current Population Reports, No. P6o-270. Washington, DC: US Government Publishing Office. https://www.cen sus.gov/content/dam/Census/library/publications/2020/demo/p6o-27o.pdf.

Shadmi, Efrat, Yingyao Chen, Inês Dourado, Inbal Faran-Perach, John Furler, Peter Hangoma, Piya Hanvoravongchai, et al. 2020. "Health Equity and COVID-19: Global Perspectives." International Journal for Equity in Health 19, article 104 (June 26): 1-16. https://doi.org/10.1186/s12939-02O-01218-z.

Siegel, Michael, Isabella Critchfield-Jain, Matthew Boykin, and Alicia Owens. 2021. "Actual Racial/Ethnic Disparities in COVID-19 Mortality for the Non-Hispanic Black Compared to Non-Hispanic White Population in 35 US States and Their Association with Structural Racism." Journal of Racial and Ethnic Health Disparities, April 27, 2021. https://doi.org/10.1007/s40615-021-01028-1.

Smith, Savannah, Jiachuan Wu, and Joe Murphy. 2020. "Map: George Floyd Protests Around the World." NBC News, June 9, 2020. https://www.nbcnews.com/news/ world/map-george-floyd-protests-countries-worldwide-n1228391.

Stanley-Baker, Michael, and Ronit Yoeli-Tlalim. 2021. "Asian Medicine and COVID-19: Ethnologies, Histories, Reflections." Asian Medicine 16, no. 1: 1-10.

Staples, Brent. 1999. "Unearthing a Riot." New York Times Magazine, December 12, 1999, pp. 64-69. https://www.nytimes.com/1999/12/19/magazine/unearthing-a-riot.html. Staples, Brent. 2020. "The Burning of Black Wall Street, Revisited." New York Times, June 19, 2020. https://www.nytimes.com/2020/06/19/opinion/tulsa-race-riot-massa cre-graves.html.

Stocking, Shannon. 2021. "U-M Research Raises Awareness of Racially Restrictive Covenants in Ann Arbor Housing." Michigan Daily, January 26, 2021. https:// www.michigandaily.com/ann-arbor/u-m-professors-reveal-racially-restrictive -covenants-ann-arbor-housing/.

Treisman, Rachel. 2021. "Darnella Frazier, Teen Who Filmed Floyd's Murder, Praised For Making Verdict Possible." NPR, April 21, 2021. https://www.npr.org/sections/ trial-over-killing-of-george-floyd/2021/04/21/989480867/darnella-frazier-teen -who-filmed-floyds-murder-praised-for-making-verdict-possib.

UnOHCHR (United Nations Office of the High Commissioner for Human Rights). 2020a. "Disproportionate Impact of COVID-19 on Racial and Ethnic Minorities 
Needs to be Urgently Addressed - Bachelet." June 2, 2020. https://www.ohchr.org/ EN/NewsEvents/Pages/DisplayNews.aspx?NewsID=25916.

UNOHCHR 2O2Ob. "Addressing the Disproportionate Impact of COVID-19 on Minority Ethnic Communities." November 24, 2020. https://www.ohchr.org/EN/HRBodies/ HRC/Pages/NewsDetail.aspx?NewsID=26541\&LangID=E.

UsCJEC (United States Congress Joint Economic Committee). 2020. The Economic State of Black America in 2020. June 11, 2020. https://www.jec.senate.gov/public/ _cache/files/ccf4dbe2-81oa-44f8-b3e 7-14f7e5143ba6/economic-state-of-black -america-202O.pdf.

Vigdor, Neil, and Daniel Victor 2021. "Over 16o Confederate Symbols Were Removed in 2020, Group Says.” New York Times, February 23, 2021. https://www.nytimes .com/2O21/02/23/us/confederate-monuments-george-floyd-protests.html.

Warner, Gregory, Joanna Kakissis, Tina Antolini, and Lu Olkowski. 2020. "The Global Legacy of George Floyd." Rough Translation (National Public Radio podcast), season 3, episode 23, June 10, 2020. https://www.npr.org/2020/o6/10/874270664/ the-global-legacy-of-george-floyd.

Wayne, Peter H., Gloria Y. Yeh, and Darshan Mehta. 2020. "Perspectives on Mindfulness Amidst the Reckoning on Race and Disparities." Journal of Alternative and Complementary Medicine 26, no. 10: 847-5o. https://doi.org/10.1089/acm.2020.0399. Weeks, John. 2020a. "The Murder of George Floyd and Demonstrations Against Systemic Racism: Responses from the Integrative Community." Integrator Blog News \& Reports, June 7, 2020. https://www.johnweeks-integrator.com/uncatego rized/the-murder-of-george-floyd-and-demonstrations-against-systemic-racism -responses-from-the-integrative-community/.

Weeks, John. 202ob. "More Integrative Responses to the Outing of Systemic Racism: Signs of Being Woke - But Are We Getting Out of Bed?" Integrator Blog News \& Reports, June 28, 2020. https://www.johnweeks-integrator.com/uncategorized/ more-in tegrative-responses-to-the-outing-of-systemic-racism-signs-of-being -woke-but-are-we-getting-out-of-bed/.

Weeks, John. 2020c. "Mending Our History: Acu-Detox Group Engages Its Black Panther and Young Lord Roots in the Time of George Floyd." Today's Practitioner, August 6, 2020. https://todayspractitioner.com/john-weeks/john-weeks-mending -our-history-acu-detox-group-engages-its-black-panther-and-young-lord-roots-in -the-time-of-george-floyd/.

Weeks, John. 2020d. "In the George Floyd Moment: Removing the 'O-Word' from Acupuncture and Eastern Medicine." Integrator Blog News \& Reports, August 15, 2020. https://www.johnweeks-integrator.com/uncategorized/in-the-george-floyd -moment-removing-the-o-word-from-acupuncture-and-eastern-medicine/. 
Weeks, John. 2020e. "In the Time of George Floyd's Murder: Update on Actions from 18 Integrative Health Organizations and Institutions." Integrator Blog News \& Reports, December 12, 2020. https://www.johnweeks-integrator.com/uncategorized/in-the -time-or-george-floyds-murder-update-on-actions-from-18-integrative-healthorganizations-and-institutions/.

Working Group of Experts on People of African Descent (UNOHCHR). 2O2O. COVID-19, Systemic Racism and Global Protests. August 21, 2020. https://www.undocs.org/A/ $\mathrm{HRC} / 45 / 44$.

Working Group of Experts on People of African Descent (UNOHCHR). 2O21. "UN Experts Condemn UK Commission on Race and Ethnic Disparities Report." April 19, 2021. https://www.ohchr.org/EN/NewsEvents/Pages/DisplayNews.aspx ?NewsID=27004\&LangID=E.

Wu, Ellen D. 2013: The Color of Success: Asian Americans and the Origins of the Model Minority. Princeton, NJ: Princeton University Press.

Zanolini, Sarah. 2020. "Alternatives to Oriental-ism." Asian Medicine Zone, September 2, 2020. http://www.asianmedicinezone.com/chinese-east-asian/alternatives-to -oriental-ism/. 